\title{
Long-term spatio-temporal genetic structure of an accidental introduction, and the population dynamics of its associated Wolbachia symbiont
}

\author{
Anne Duplouy ${ }^{1}$, Abhilash Nair ${ }^{1}$, Toshka Nyman ${ }^{1}$, and Saskya van Nouhuys ${ }^{2}$ \\ ${ }^{1}$ University of Helsinki \\ ${ }^{2}$ Cornell University
}

August 23, 2020

\begin{abstract}
Population bottlenecks associated with founder events strongly impact the establishment and character of populations. Founding individuals bring along symbionts, which can affect the host establishment, dynamics and evolution. Thus, to understand introductions and invasions, we should identify the roles played by accompanying symbionts. In 1991, a parasitoid wasp and its associated hyperparasitoid were accidentally introduced from the main Åland islands to an isolated island in the archipelago, along with their host, the Glanville fritillary butterfly. The species have persisted as small populations since. A strain of the endosymbiotic bacterium Wolbachia has an intermediate prevalence across the main Åland parasitoid population. The infection increases susceptibility of the parasitoid to hyperparasitism. We investigated the establishment and dynamics of the parasitoid, along with pattern of prevalence of the symbiont using 324 specimens collected between 1992 and 2013, from five localities across Åland, including the source and introduced populations. Using 14 microsatellites and one mitochondrial marker, we suggest that occasional migration between the islands might have facilitated the persistence of all isolated populations, despite local population crashes. We also show local near-fixation of Wolbachia, where the hyperparasitoid is absent, and selection against infected host genotypes is relaxed.
\end{abstract}

\section{Introduction}

Introduced and invading populations generally show low genetic variability, and a different genetic structure than in their native range, due to small founder populations, and demographic bottlenecks (Hufbauer, Bogdanowicz, \& Harrison, 2004). Low genetic variability may in turn influence population level dynamics, persistence, and evolutionary potential of introduced populations (Fauvergue, Vercken, Malausa, \& Hufbauer, 2012; Szucs, Melbourne, Tuff, \& Hufbauer, 2014). The individuals founding new populations usually bring along various symbiotic passengers. A common example of such a symbiont is the $\alpha$-Proteobacterium Wolbachia pipientis - a maternally inherited endosymbiotic bacterium that infects over $40 \%$ of insect species (Detcharoen, Arthofer, Schlick-Steiner, \& Steiner, 2019). Wolbachia can be intimately involved in the biology of their hosts, through either manipulating the host reproductive system (O'Neill, Hoffman, \& Werren, 1997), susceptibility to predators, parasites or pathogens (Fytrou, Schofield, Kraaijeveld, \& Hubbard, 2006; Hedges, Brownlie, O'Neill, \& Johnson, 2008; Osborne, Iturbe-Ormaetxe, Brownlie, O'Neill, \& Johnson, 2012; van Nouhuys, Kohonen, \& Duplouy, 2016), metabolism (Gruntenko et al., 2017; Gruntenko et al., 2019), or dispersal capacities (Evans et al., 2009). Wolbachia -mediated costs and benefits have been shown to affect host population dynamics (Charlat et al., 2009; Duplouy, Hurst, O’Neill, \& Charlat, 2010; Verne, Johnson, Bouchon, \& Grandjean, 2012), select for particular host genotypes (Signor, 2017), or even hamper the evolution of host traits in infected populations (Martinez et al., 2016). Consequently, studying spatio-temporal patterns in the penetrance and prevalence of symbionts in host populations along with the genetic structure 
of introduced and original host populations, can provide crucial insights into how both intentionally and accidentally introduced species may successfully establish, persist and further disperse across habitats $(\mathrm{Lu}$, Hulcr, \& Sun, 2016).

The Glanville fritillary butterfly, Melitaea cinxia (L.) (Lepidoptera: Nymphalidae) lives as a classical metapopulation in Åland, Finland (I. Hanski, Pakkala, Kuussaari, \& Lei, 1995). The (meta)population ecology and dynamics of the butterfly and associated community of parasitoid species has been under study since the early 90's (van Nouhuys \& Hanski, 2005), revealing, for example, that the butterfly population dynamics dictates the population sizes of its associated parasitoids (I. Hanski et al., 2017). In August 1991, seventy-two families of gregarious $M$. cinxia caterpillars were intentionally introduced on the island of Sottunga, on the East side of the Åland archipelago (Fountain et al., 2018; I. Hanski et al., 2004; I. Hanski et al., 2017). Through natural parasitism of about a third of the introduced butterfly larvae, the specialist parasitoid waspHyposoter horticola (Gravenhorst) (Hymenoptera: Ichneumonidae: Campoplaginae), and its own specialist hyperparasitoid Mesochoruscf. stigmaticus (Hymenoptera: Ichneumonidae: Mesochorinae) (I. Hanski et al., 2004; G. C. Lei, Vikberg, Nieminen, \& Kuussaari, 1997; Montovan, Couchoux, Jones, Reeve, \& van Nouhuys, 2015; Shaw, Stefanescu, \& Van Nouhuys, 2009; van Nouhuys \& Ehrnsten, 2004) were simultaneously accidentally introduced in Sottunga. As they make up the highest trophic levels of insect communities, parasitoids are extremely sensitive to the spatio-temporal dynamics and structure of their host resources (Cronin \& Reeve, 2005; Gagic et al., 2012; Gagic et al., 2011; Kaartinen \& Roslin, 2011; Nair, Fountain, Ikonen, Ojanen, \& van Nouhuys, 2016; van Nouhuys, 2005). Nonetheless, despite occasional strong bottlenecks through local butterfly population crashes (Fountain et al., 2016; I. Hanski et al., 2004; van Bergen et al., 2020), the three species have persisted on Sottunga, more than $30 \mathrm{~km}$ away from the mainland population, and more than $12 \mathrm{~km}$ away from any other island population. In this system, Wolbachia is only known to infect the parasitoid wasp, H. horticola (Duplouy, Couchoux, Hanski, \& van Nouhuys, 2015). In Åland, the host population infection occurs at an intermediate and stable rate of about [?]50\% across the archipelago (Duplouy et al., 2015), but the local prevalence of the bacterium differs between the mainland and neighbouring isolated islands (Duplouy et al., 2015), and the infection is more often associated to one of the two previously described mitochondrial haplotypes of the host (Duplouy et al., 2015). Finally, the infection is costly and increases, by almost two folds, the susceptibility of infected individuals to the hyperparasitoid (van Nouhuys et al., 2016), which itself varies in prevalence and rate of hyperparasitism across local populations in Aland (Montovan et al., 2015; Nair et al., 2016).

We analysed spatio-temporal variations in both the genetic structure of the parasitoid host, H. horticola, and the infection rate of the parasitoid by the endosymbiont Wolbachia on the island of Sottunga, and four other regions in the Aland islands. We used 14 nuclear microsatellite markers and one mitochondrial marker to genotype 324 wasps, to infer history and outcome of the accidentally introduced small population, over a 22year period (1992-2013), and screened the wasps for infection with Wolbachia over the same period. We investigated (1) whether gene flow occurred after the accidental introduction of the parasitoid species on the island of Sottunga, and migrations supported persistence of the neighbouring island populations despite occasional population crashes, and (2) whether variations in the local levels of hyperparasitism selected for Wolbachia -infected or uninfected host genotypes in isolated local populations.

\section{Material and method:}

\section{Insect material}

The entire metapopulation of the Glanville fritillary butterfly (Melitaea cinxia , L.) in the Aland archipelago, Southwest Finland (60deg13'N 19deg55'E, Figure 1a), has been surveyed for more than two decades as part of a long-term ecological study of its metapopulation dynamics (Ojanen, Nieminen, Meyke, Poyry, \& Hanski, 2013). Caterpillars have been irregularly collected since the 90 's, and systematically collected as part of the annual survey between 2008 and 2014 (Fountain et al., 2016; I. A. Hanski, 2011). A fraction of the field collected caterpillars are naturally parasitized by the solitary endoparasitoid wasp $H$. horticola, some of which in turn are hyperparasitized by M. stigmaticus (Montovan et al., 2015; Shaw et al., 2009; van Nouhuys \& Hanski, 2005). About half the H. horticola in Aland are infected by Wolbachia, which does not have a 
direct impact on several individual wasp fitness traits, including dispersal, longevity, and egg production (Duplouy et al., 2015), but which increases the susceptibility of the wasp to its hyperparasitoidMesochorus cf. stigmaticus (van Nouhuys et al., 2016).

Before 1991, the Glanville fritillary butterfly, the parasitoid and the hyperparasitoid did not inhabit Sottunga, but the butterfly at least was known to inhabit nearby islands of Foglo, Seglinge and Kumlinge (I. Hanski et al., 2004; Murphy, Wahlberg, Hanski, \& Ehrlich, 2004). The caterpillars introduced on to Sottunga in 1991 originated from the mainland Aland in northern Finstrom (Hanski pers. Comm.), where the parasitoid was common (G. Lei \& Hanski, 1998). Since 1991, the butterfly (Fountain et al., 2016) and the parasitoid wasp populations (Couchoux, Seppa, \& van Nouhuys, 2016) have persisted despite going through occasional strong local population bottlenecks (Figure 2). The butterfly and its parasitoid wasps are not classified as endangered or protected and hence no permits are required for their collection in the Aland Islands.

We selected $324 \mathrm{H}$. horticola parasitoid individuals, including both males and females, reared from different butterfly host nests sampled from five localities in the Aland archipelago between 1992 and 2013 (Ojanen et al., 2013). In total, we used 40 wasps from the island of Sottunga (60deg07'N 20deg 40'E), 43 from the northern islands of Foglo (60deg03'N 20deg32'E, in areas called Jyddo, Noto, and Overo), 44 from the closely adjacent islands of Seglinge-Kumlinge (60deg14'N 20deg46'E, 14 samples from Kumlinge, others from Seglinge), 96 from northern Finstrom (60deg32'N 19deg95'E) and 101 from Saltvik (60deg16'N 20deg03'E) on the main Aland island (Figure 1). See Table 1 for sample size for each year at the different populations. The chance of collecting full-siblings in this sample is low (Couchoux, Seppa, \& van Nouhuys, 2015a). The coast-to-coast distances between Sottunga and Seglinge, and between Sottunga and Foglo, are of 8,5km and $6,5 \mathrm{~km}$, respectively, while the closest distance between the two suitable habitat patches on different islands is $12 \mathrm{~km}$ and $13 \mathrm{~km}$, respectively. The distance from a mainland area to a suitable patch on Sottunga is about $30 \mathrm{~km}$.

\section{Samples preparation}

All $H$. horticola wasps emerging from the field-collected caterpillars were individually preserved in ethanol in the freezer $(-20 \mathrm{degC})$ until use. The DNA was extracted from the abdomen of each wasp using a Qiagen DNeasy blood and tissues extraction kit, following the manufacturer's protocol (Qiagen(r), USA). We amplified the mitochondrialCOI gene by PCR using the primer pair LCO/HCO developed by Folmer et al. (Folmer, Black, Hoeh, Lutz, \& Vrijenhoek, 1994).

\section{Mitotype and Wolbachia-infection status}

Cytoplasmic entities such as the mitochondria and Wolbachiasymbionts are passed on only from mothers. These maternally inherited entities can thus change frequency in a population at different rates than genotypes determined using nuclear microsatellite markers. To evaluate maternal inheritance, we sequenced a mitochondrial gene and screened for Wolbachia in the majority of our samples.

Two common H. horticola mitotypes were previously characterised from the Aland islands (Duplouy et al., 2015). We determined the mitotype of 222 wasps picked at random from the 324 samples genotyped above (37 from Finstrom, 41 from Foglo, 43 from Seglinge-Kumlinge, 63 from Saltvik and 38 from Sottunga) by direct Sanger sequencing theCOI gene described above using an ABI 3730 DNA Sequencer (Applied Biosystems $^{\mathrm{TM}}$, USA). These samples included males and females from the five localities and each collection year.

Duplouy et al. (Duplouy et al., 2015) showed earlier that about $50 \%$ of the $H$. horticola population on the Aland islands is infected by the Wolbachia strain $w$ Hho. We screened for $w$ Hho in 296 samples (90 from Finstrom, 41 from Foglo, 40 from Seglinge-Kumlinge, 86 from Saltvik and 39 from Sottunga), picked at random from the 324 samples genotyped above, using the primer pair $81 \mathrm{~F} / 691 \mathrm{R}$ to amplify the conserved Wolbachia wsp gene (Zhou, Rousset, \& O'Neil, 1998).

Microsatellite genotyping 
To document temporal and spatial nuclear genetic variation in $H$. horticola wasps, we genotyped a total of 324 wasps (124 males/194 females/6 unknown) using the 14 microsatellite-loci developed by Couchoux et al. (Couchoux, Seppa, \& van Nouhuys, 2015b). The forward primers were labelled with either FAM, HEX, or TAMRA fluorescent dye (DNA Technology A/S), and used in multiplex non-overlapping PCR reactions using Qiagen Multiplex PCR kit as described by Couchoux et al. (Couchoux et al., 2015b). Diluted PCR products were genotyped on an automated ABI 3730 DNA Sequencer (Applied Biosystems ${ }^{\text {TM }}$, USA). The sizes were called using Genescan-500 ROX size standard. We manually curated the genotypes for each sample using the GeneMapper(r) Software 5 (Applied Biosystems ${ }^{\text {TM }}$, USA). Several samples were independently genotyped multiple times to clarify uncertainties in the genotypes.

For the purpose of the genetic analyses described below, we separated the samples into the five localities they were collected from (North Finstrom, North Foglo, Seglinge-Kumlinge, Saltvik or Sottunga, Figure 1b), or into 12 spatio-temporal groups according to their geographic origin and their collection time interval (Finstrom 1992-97, 2003-08, 2009-11, Foglo 2000-09, 2010-13, Seglinge-Kumlinge 2000-09, 2010-11, Saltvik 1999, 2005-09, 2010-13, and Sottunga 2002-04, 2005-09, Figure 3, Table 2). Each of the 12 spatio-temporal groups was designed in an attempt to include specimens from either the 90's, the 2000's, and the 2010's from each locality. Due to the lack of samples from other decades, the samples from Sottunga were divided between the early and the late 2000's groups.

We analysed the genetic structure of wasps collected from the five localities and the spatio-temporal groups using two independent spatial Bayesian clustering analyses, with the 'clustering of groups of individuals' settings implemented in the BAPS software (Corander, Marttinen, Siren, \& Tang, 2008; Corander, Waldmann, \& Sillanpaa, 2003). We ran two spatial Bayesian clustering analyses with respective admixture analyses (Figure 3) to evaluate the degree of admixture at each locality, and in each locality through time. We used the software GenoDive 2.0b27 (Meirmans \& van Tienderen, 2004) to calculate population genetics measures using only the samples that were successfully genotyped for at least seven microsatellite markers $(\mathrm{N}=309)$. Hymenoptera males are haploid while females are diploid. The analyses described above were thus conducted twice: (1) with both sexes included, but all males considered as homozygote diploids in order to fit the input format of the software used to define the different genetic clusters/genotypes, and (2) with only the females, to avoid overestimating the impact of the haploid males. We tested Hardy-Weinberg equilibrium at each locus in each locality and for each of the 12 spatio-temporal groups (Table 3). We also calculated the $\mathrm{F}_{\mathrm{ST}}$-values between localities and between the 12 spatio-temporal groups. Finally, using only the female samples, we calculated the observed $\left(H_{O}\right)$ and expected heterozygosity $\left(H_{E}\right)$ at each locus, as well as the inbreeding coefficient (Fis ).

\section{Results}

\section{Genotypes and mitochondrial haplotypes}

We successfully genotyped 7 to 14 microsatellite markers from of 324 samples (Table S1). Although the Bayesian clustering of individuals analysis $\left(\mathrm{N}_{\mathrm{pop}}=1\right)$ resolved to 31 genetic clusters $(\mathrm{k}=31, \mathrm{p}=0.999$, Appendix 1), both the spatial Bayesian clustering analysis of five localities $\left(\mathrm{N}_{\mathrm{Pop}}=5, \mathrm{k}=4, \mathrm{p}=0,999\right.$; Appendix 2 ), and the spatial Bayesian clustering analysis of 12 spatio-temporal groups $\left(\mathrm{N}_{\mathrm{pop}}=12\right)$, detected only four genetically differentiated population clusters $\left(\mathrm{N}_{\mathrm{pop}}=12, \mathrm{k}=4, \mathrm{p}=0.999\right.$; Appendix 3). Additionally, spatial Bayesian analyses including all genotyped female individuals based on both the five localities and the 12 spatio-temporal groups, suggest restricted gene flow between the four clusters, and across generations.

Both the five localities and the 12 spatio-temporal groups analyses suggest that Sottunga and SeglingeKumlinge are genetically similar to one another (Appendix 3). In the Bayesian clustering of localities $\left(\mathrm{N}_{\text {Pop }}=5\right)$ analysis, Sottunga and Seglinge-Kumlinge populations made up one cluster ( $\mathrm{FST}=0.014, \mathrm{p}=0.042$, Table 3), and Foglo, Finstrom and Saltvik each made up the three other clusters (Figure 1c). Although the clustering analysis of the 12 spatio-temporal groups in general support these same clusters, it also reveals that the early samples from Foglo and Finstrom, and all samples from Saltvik, group in the same cluster (red). The two island populations (Sottunga and Seglinge-Kumlinge) are always found to be genetically different 
from Foglo ( $\mathrm{FST}=0.113, \mathrm{p}=0.001$, Table 3$)$. The shared ancestry of the Sottunga and Finstrom samples is visible through detailed screening of the individual cluster dataset $\left(\mathrm{N}_{\mathrm{pop}}=1\right.$, Appendix 1). The samples collected in Sottunga belong to 13 genotypes, five of which (genotypes \#9,11, 14, 17 and 26) also include samples from Finstrom collected in 1992 and 1993. These same five genotypes include most of the samples from Kumlinge-Seglinge ( $\mathrm{N}=32 / 42,76 \%$ ), and are also found in other localities (Appendix 1), suggesting shared ancestry within each of the populations.

In general, the admixture analyses revealed little gene flow and interbreeding between the four clusters (Figure 3). We observe some gene flow between Foglo and Sottunga, between Foglo and Saltvik (possibly as a result of dispersal through several generations, or stepping stone events), as well as between the two mainland populations of Saltvik and Finstrom (as a result of dispersal between the two neighbouring regions) (Figure 3). Additionally, consistent with Couchoux et al. (2016), inbreeding occurs in Aland at similarly low levels in each of the five localities, despite the mainland populations being of more connected, and of larger sizes. The inbreeding coefficient (Fis ), generally about 0,222 across Aland, ranges from 0,174 in Saltvik, and 0,258 in Foglo (Table 3); while reaching 0,206 in Sottunga.

The parasitoid H. horticola in Aland has experienced both global and local population crashes through the years (Figure 2), some of which resulted in detectable changes in local genetic structure. The genotype characterizing Foglo after the population crash of 2010 (Figure 1) is from a different genetic cluster than any of the three other clusters characterized from the other four populations. In contrast, other local crashes, for example in 1999 and 2006 in Finstrom, and in 1999 in Saltvik, did not affect the genotypic clusters of these populations. Unfortunately, we lack data to directly address the impact of bottlenecks that occurred in both Seglinge-Kumlinge and Sottunga.

Finally, in agreement with a previous study by Duplouy et al. (2015), the majority of the H. horticola parasitoids carry the C-mitotype $(\mathrm{N}=145,67 \%)$, while the remaining specimens carry the T-mitotype (Table 1). Noticeably, the C-mitotype is prevalent in all localities (57\% in Saltvik, $71 \%$ in Sottunga, $84 \%$ in Finstrom, 95\% in Foglo) except Seglinge-Kumlinge (28\%) (Table 1). These general patterns hold across the different spatio-temporal groups (Table 2).

Wolbachia infection status

Wolbachia was detected in samples from all five localities. The mean infection rate across our samples is $50 \%$, which is consistent with previous work from Duplouy et al. (2015) across the entire Aland archipelago. Among the localities, Seglinge-Kumlinge shows the highest infection rate (95\%), greatly contrasting with the lower infection rates of Finstrom (42\%), Foglo (32\%), Saltvik (59\%), and Sottunga (23\%) (Table 1).

Among all Wolbachia -infected wasp sampled for the present study, 57\% carry the T-mitotype, which is also consistent with the intermediate infection rate from across the entire Aland archipelago, as characterized by Duplouy et al. (2015). However, the proportion of infected wasps carrying the T-mitotype differed among localities. In Saltvik, Finstrom and Foglo, only 60\%, 33\% and 0\% of Wolbachia -infected wasps carry the T-mitotype, respectively. In contrast, despite the two islands showing contrasting proportions of specimens carrying the T-mitotype (see above), Sottunga and Seglinge-Kumlinge are once again more similar to each other than to any other population, with the majority of Wolbachia- infected wasps carrying the T-mitotype ( $75 \%$ and $79 \%$, respectively) rather than the C-mitotype. Finally, the four most common genotypes in Seglinge-Kumlinge (Genotype -5 (N=13); -6 (N=6); -9 $(\mathrm{N}=6)$; and $-17(\mathrm{~N}=6)$ ) are found in strict associations with Wolbachia- infected wasps, but all mainly carry the T-mitotype (mean of 77\%; genotype $-5(54 \%),-6(83 \%),-9(100 \%),-17$ (100\%), respectively). This contrasts with the rest of Aland, including Sottunga, where these four genotypes are not strongly associated with Wolbachia, and more rarely in association with the T-mitotype than with the C-mitotype (mean of $21 \%$; genotype $-5(11 \%),-6(0 \%)$, $-9(29 \%),-17(50 \%))$. All other genotypes in the Seglinge-Kumlinge sample are represented by less than 3 samples, and thus it is difficult to determine patterns from them.

\section{Discussion}


The introduction and long-term persistence of the parasitoid wasp $H$. horticola in the small island of Sottunga, on the East side of the Aland archipelago, offered a unique opportunity to investigate the spatio-temporal changes in the genetic structure, dispersal, and dynamics of a species introduced into a new habitat. Because the parasitoid carried along its Wolbachia symbiont, we could also investigate how symbionts might affect the spread of different host genotypes after introduction. Our results suggest that the H. horticola population that established in Sottunga persisted despite strong bottlenecks both during the founder event, and across its 22 years of persistence. Additionally, the introduction affected the genetic pool of the insect communities inhabiting the nearby islands through dispersal of individuals carrying the mainland genotypes, and by the establishment of populations carrying a costly Wolbachiastrain.

Spatio-temporal genetic changes - the role of a local introduction

Couchoux et al. (2016) had already suggested some geneflow between the H. horticola parasitoid population in Sottunga and the neighbouring northern population inhabiting the Seglinge-Kumlinge islands. Many genotypes found in the original population of Finstrom were also characterized from wasps from Sottunga and Seglinge-Kumlinge. The movement of genotypes over long distances such as the one separating the islands from the mainland might occur over several generations of gene flow through interbreeding (Couchoux et al., 2016; DiLeo, Husby, \& Saastamoinen, 2018), but it is simply more likely that, instead, the genotypes introduced in Sottunga in 1991 have persisted over time on the island, and have dispersed to colonise the islands of Seglinge-Kumlinge in the North. In contrast, the mainland genotypes are not found in $H$. horticola from the southern islands of Foglo, which is about the same distance from Sottunga than Seglinge is, suggesting restricted gene flow towards Foglo.

The coast-to-coast distances between Sottunga and the neighbouring islands of Seglinge or Foglo are at least $6,5 \mathrm{~km}$, with about $12 \mathrm{~km}$ as the shortest distances between known suitable habitat patches on the two islands (Ojanen et al., 2013). The parasitoid wasp H. horticolais a much better disperser than its butterfly host (van Nouhuys \& Hanski, 2002), commonly flying over $1 \mathrm{~km}$ distance, and travelling up to $7,5 \mathrm{~km}$ within a breeding season (Couchoux et al., 2016). The flight capacity of the parasitoid allows it to disperse across unsuitable habitats on the mainland, but is most likely not sufficient to cross stretches of open water separating two islands, or the $30 \mathrm{~km}$ separating the mainland from the shores of Sottunga. Insects can however move across large unsuitable habitats under prevailing winds (Compton, 2002; Pasek, 1988). In the Baltic Sea, a dominant wind blowing from the South (Bierstedt, Hunicke, \& Zorita, 2015) could transport wasps from Sottunga to Seglinge-Kumlinge, as well as inhibit southward movements towards Foglo. Insects can also be moved by humans intentionally or incidentally (Kritani \& Yamamura, 2003). One of the host plants of the Glanville fritillary butterfly, Veronica spicata (Kuussaari, van Nouhuys, Hellmann, \& Singer, 2004) produces indigo blue flower spikes that may be of interests to gardeners on the different islands. The humanassisted migration of $H$. horticola within their host caterpillars feeding on plants (Carlsson, Haeggstrom, \& Sundberg, 2014), although possible, has not been suggested from any population genetic studies conducted on the Aland butterfly populations (Fountain et al., 2018; Fountain et al., 2016).

While the butterfly was known to occupy Seglinge-Kumlinge prior to year 2000, there is no historical record of the parasitoid $H$. horticola, and we did not find any unique genotypes nor mitotypes in those islands. Rather, the current parasitoid population on Seglinge-Kumlinge bares resemblance to the introduced parasitoids from Sottunga, suggesting that H. horticola may have been absent from Seglinge-Kumlinge prior to its introduction to Sottunga and subsequent colonization of Seglinge-Kumlinge. If this is true, prior to the $H$. horticola introduction, the Seglinge-Kumlinge butterfly population may have been free of the parasitoid, which is significant for the butterfly population because where present, H. horticolaparasitizes about $30 \%$ of the host larvae (Montovan et al., 2015). To date, it remains unclear whether the introduction of the parasitoid to Seglinge-Kumlinge, where the butterfly had persisted without a specialist parasitoid, has had any influence on the eco-evolutionary dynamics of this local butterfly population.

There are many examples of the effect of isolation on the genetics of introduced Island populations (Hufbauer et al., 2004; Mattila et al., 2012; Miller, Eldridge, Morris, Zenger, \& Herbert, 2011; Szucs et al., 2014; Urquia et al., 2019), including a study of human population on the island of Sottunga (O'Brien, Jorde, Ronnlof, 
\& Eriksson, 1988). Generally, these small isolated populations show low allelic diversity, low heterozygosity and high inbreeding values (Fauvergue et al., 2012; Mattila et al., 2012; Nei, Marutama, \& Chakraborty, 1975). The Sottunga population of the parasitoid wasp H. horticola , as well as the isolated populations of Foglo (South) and of Seglinge-Kumlinge (North), show slightly lower heterozygocity (Ho [?]0.3) than the large mainland populations (Ho [?]0.4). This is probably due to loss of genetic diversity in the islands during the founder event and/or following local population crashes. However, heterozygosity remains relatively high compared to studies from other similarly isolated animal populations (O'Brien et al., 1988). Furthermore, all five populations show similar degrees of inbreeding without strong differences between mainland and island populations ( Fis $=0.18$ and 0.23 in the mainland populations, while Fis values vary between 0.21 and 0.24 in the three island populations). This pattern of genetic variability contrasts our original expectations. However, rapid population growth after bottleneck and high dispersive ability are known to counteract the effect of small population size and isolation on both the loss of heterozygosity and inbreeding (Nei et al., 1975).

Spatio-temporal genetic changes - the effect of Wolbachia

infection

While the Wolbachia strain $w$ Hho occurs at an intermediate prevalence across the Aland Islands (Duplouy et al., 2015), on the islands of Seglinge-Kumlinge, it has been almost at fixation since the year 2000, and potentially earlier. As shown by Duplouy and colleagues (2015), this particular Wolbachia strain appears not to affect dispersal capacity of $H$. horticola , thus the high Wolbachia prevalence in Seglinge-Kumlinge is unlikely to be related to differential dispersal of infected wasps to these islands. In contrast, $w$ Hho-infected wasps are more susceptible to hyperparasitism by the specialist hyperparasitoid wasp Mesochoruscf. stigmaticus (van Nouhuys et al., 2016). Mesochorus cf.stigmaticus is common across the Aland mainland (Nair et al., 2016), and is also present in Sottunga and Foglo (van Nouhuys \& Hanski, 2005). The hyperparasitoid wasp restrains the spread of $w$ Hho in $H$. horticola by keeping the infection at lower prevalence when highly abundant (van Nouhuys et al., 2016), while the absence ofM. cf. stigmaticus in Seglinge-Kumlinge (Nair et al., 2016; van Nouhuys \& Hanski, 2005; van Nouhuys et al., 2016) releases the selection pressure on $w$ Hho-infected $H$. horticolawasps, and allows the spread of the symbiont in this isolated wasp population (van Nouhuys et al., 2016).

The spread of a maternally inherited symbiont, such as Wolbachia, may lead to a simultaneous increase in prevalence of the mitochondrial genotypes carrying the symbiont, as selection on the symbiont will promote the fitness of the infected genotypes (Charlat et al., 2009; Duplouy et al., 2010; Schuler et al., 2016). In $H$. horticola in Aland, C- and T-mitotypes associate with the $w$ Hho infection, but the C-mitotypes are less associated with the infection, potentially because the trans-generation transmission of this Wolbachiastrain is less efficient in females carrying the C- over the T-mitotype (Duplouy et al., 2015). Consequently, we expected that the T-mitotype would be found at low frequency in Seglinge-Kumlinge, as it was in the original population of Finstrom (16\%), as well as in Sottunga (29\%). Instead, we found that the T-mitotype is prevalent in Seglinge-Kumlinge $(72 \%)$. The spread of the wasps carrying the T-mitotype in SeglingeKumlinge could result from: (I) the selective sweep of the T-matriline during the spread of Wolbachia in Seglinge-Kumlinge in the absence of pressures from the hyperparasitoid, (II) strong bottlenecks randomly selecting for individuals from the T-matriline over the C-matriline in Seglinge-Kumlinge during migration events from Sottunga; and (III) uncharacterized fitness benefits associated with the T- mitotype. According to our data, all genotypes in Seglinge-Kumlinge are found in the rest of Aland, which suggests that several migration events have occurred between the two populations over the 22 years period of our study. This rate of migration considerably reduces the probability of a high frequency of the T- mitotype in Seglinge-Kumlinge due to bottlenecks, especially because the C-mitotype is significantly more prevalent in the source population of Sottunga. It is then more likely that selection acts on the wasps after migration in Seglinge-Kumlinge. Additionally, there is currently no evidence that the T-mitotype provides any benefit to its host, as it is generally rare across Aland (Duplouy et al., 2015). Consequently, the high prevalence of the T-mitotype in Seglinge-Kumlinge is most likely due to the spread of $w$ Hho under relaxed predation pressures in this 
island.

\section{Conclusion}

The study of invasion, and of accidental or intentional introductions of species are central to much of contemporary population and community ecology (Davis, 2009). Parasitoids are used as insect biological control agents (Wang, Liu, Shi, Huang, \& Chen, 2019). Consequently, they are intentional introduced into both agricultural and natural environments (Grangirard, Hoddle, Petit, Roderick, \& Davies, 2009) but often these introductions do not persist in the long term (Goldson et al., 2014), and if they do, their genetic structures might differ (Hufbauer et al., 2004). Brought along during the introduction events, associated symbionts can impact the success story of their host populations, by affecting the phenotypes and genotypes of their hosts (Charlat et al., 2009; Hornett et al., 2006). We use genetic evidence to document the trajectory of a successful introduced parasitoid population over 22 years. We show persistence of the wasp on the previously uninhabited island, and spread of the transplanted genotypes to surrounding island populations, along with the associated symbiotic bacterium Wolbachia. The shuffling of the nuclear and matrilineally inherited markers among islands suggests differential selection for the infection-associated genotypes in the local host genetic pools under relaxed predation pressures in an island where the hyperparasitoid species is absent (van Nouhuys et al., 2016). The establishment of newly introduced parasitoid genotypes might contribute to either the persistence of the isolated island wasp populations, or the replacement of the local wasp populations, or both. It may have also changed environment for the pre-existing nearby isolated butterfly host population, which previously did not have the parasitoid. The Glanville fritillary butterfly is vulnerable to loss of genetic variability and extinction in the Baltic Sea region due to habitat fragmentation, and has gone extinct from the Turku archipelago in southwest Finland (Fountain et al., 2016). The spread of an introduced parasitoid population can represent another pressure for the host population, as well as any competing local parasitoid populations (Benson, Van Driesche, Pasquale, \& Elkinton, 2003; Benvenuto, Cheyppe-Buchmann, Bermond, Ris, \& Fauvergue, 2012). This is especially true if newly introduced parasitoid genotypes show greater fitness than native genotypes (Dupas, Dubuffet, Carton, \& Poirie, 2009; Kraaijeveld, Van Alphen, \& Godfray, 1998; van Nouhuys, Niemikapee, \& Hanski, 2012).

\section{Acknowledgements:}

We thank C. Couchoux for advice on the genotyping work, S. Ikonen for rearing the insects, and S. Ojanen and many students from the University of Helsinki, who conducted the annual survey and collected the samples. We are grateful to I. Hanski and P. Seppa for their interest in and constructive discussions about the study. This work was supported by the Academy of Finland (grant \#266021 to AD, and \#255553 to SvN).

\section{References}

Benson, J., Van Driesche, R. G., Pasquale, A., \& Elkinton, J. (2003). Introduced braconid parasitoids and range reduction of a native butterfly in New England. . Biological control, 28 (2), 197-213. doi:10.1016/S1049-9644(03)00058-6

Benvenuto, C., Cheyppe-Buchmann, S., Bermond, G., Ris, N., \& Fauvergue, X. (2012). Intraspecific hybridization, life history strategies and potential invasion success in a parasitoid wasp. Evolutionary Ecology, 26 , 1311-1329. doi:10.1007/s10682-011-9553-z

Bierstedt, S. E., Hunicke, B., \& Zorita, E. (2015). Variability of wind direction statistics of mean and extreme wind events over the Baltic Sea region. Tellus A: Dynamics Meteorology and Oceanography, 67 (1), 29073. doi:10.3402/tellusa.v67.29073

Carlsson, R., Haeggstrom, C.-A., \& Sundberg, K. (2014). Ruderal vascular plants on a waste ground in the island of Dano, Aland Islands, SW Finland. Memoranda Societatis pro Fauna et Flora Fennica, 90 , 55-66.

Charlat, S., Duplouy, A., Hornett, E. A., Dyson, E. A., Davies, N., Roderick, G. K., . . . Hurst, G. D. (2009). The joint evolutionary histories of Wolbachia and mitochondria in Hypolimnas bolina . BMC Evol 
Biol, 9 , 64. doi:10.1186/1471-2148-9-64

Compton, S. G. (2002). Sailing with the wind: dispersal by small flying insects. In J. M. Bullock, R. E. Kenward, \& R. S. Hails (Eds.),Dispersal ecology: 42nd symposium of the British ecological society (Vol. 113-133). Oxford: Blackwell.

Corander, J., Marttinen, P., Siren, J., \& Tang, J. (2008). Enhanced Bayesian modelling in BAPS software for learning genetic structures of populations. BMC Bioinformatics, 9 , 539 .

Corander, J., Waldmann, P., \& Sillanpaa, M. L. (2003). Bayesian analysis of genetic differentiation between populations. Genetics, $163,367-374$.

Couchoux, C., Seppa, P., \& van Nouhuys, S. (2016). Strong dispersal in a parasitoid wasp overwhelms habitat fragmentation and host population dynamics. Mol Ecol, 25 (14), 3344-3355. doi:10.1111/mec.13696

Couchoux, C., Seppa, P., \& van Nouhuys, S. (2015a). Behavioural and genetic approaches to evaluate the effectiveness of deterrent marking by a parasitoid wasp. Behaviour, 152 (9), 1257-1276. doi:10.1163/1568539X00003277

Couchoux, C., Seppa, P., \& van Nouhuys, S. (2015b). Microsatellites for the parasitoid wasp Hyposoter horticola . Conservation Genetics Resources, 7 , 595-597.

Cronin, J. T., \& Reeve, J. D. (2005). Host parasitoid spatial ecology: a plea for a landscape-level synthesis. Proceedings of the Royal Society B: Biological Sciences, 272 (1578), 2225-2235. doi:10.1098/rspb.2005.3286

Davis, M. A. (2009). Invasion biology : Oxford University Press.

Detcharoen, M., Arthofer, W., Schlick-Steiner, B. C., \& Steiner, F. M. (2019). Wolbachia megadiversity: 99\% of these microorganismic manipulators unknown. FEMS Microbiol Ecol, 95 (11). doi:10.1093/femsec/fiz151

DiLeo, M. F., Husby, A., \& Saastamoinen, M. (2018). Landscape permeability and individual variation in a dispersal-linked gene jointly determine genetic structure in the Glanville fritillary butterfly.Evolution Letters, 2 (6), 544-556. doi:10.1002/evl3.90

Dupas, S., Dubuffet, A., Carton, Y., \& Poirie, M. (2009). Local, geographic and phylogenetic scales of coevolution in Drosophila-parasitoid interactions. Adv Parasitol, 70 , 281-295. doi:10.1016/S0065-308X(09)700119

Duplouy, A., Couchoux, C., Hanski, I., \& van Nouhuys, S. (2015). Wolbachia Infection in a Natural Parasitoid Wasp Population.PLoS One, 10 (8), e0134843. doi:10.1371/journal.pone.0134843

Duplouy, A., Hurst, G. D., O'Neill, S. L., \& Charlat, S. (2010). Rapid spread of male-killing Wolbachia in the butterfly Hypolimnas bolina . J Evol Biol, 23 (1), 231-235. doi:10.1111/j.1420-9101.2009.01891.x

Evans, O., Caragata, E. P., McMeniman, C. J., Woolfit, M., Green, D. C., Williams, C. R., . . . McGraw, E. A. (2009). Increased locomotor activity and metabolism of Aedes aegypti infected with a life-shortening strain of Wolbachia pipientis . J Exp Biol, 212 (Pt 10), 1436-1441. doi:10.1242/jeb.028951

Fauvergue, X., Vercken, E., Malausa, T., \& Hufbauer, R. A. (2012). The biology of small, introduced populations, with special reference to biological control. Evol Appl, 5 (5), 424-443. doi:10.1111/j.17524571.2012.00272.x

Folmer, O., Black, M., Hoeh, W., Lutz, R., \& Vrijenhoek, R. (1994). DNA primers for amplification of mitochondrial cytochrome c oxidase subunit I from diverse metazoan invertebrates. Mol Mar Biol Biotechnol, 3 (5), 294-299.

Fountain, T., Husby, A., Nonaka, E., DiLeo, M. F., Korhonen, J. H., Rastas, P., . . . Hanski, I. (2018). Inferring dispersal across a fragmented landscape using reconstructed families in the Glanville fritillary butterfly. Evolutionary Applications, 11 (3), 287-297. doi:10.1111/eva.12552 
Fountain, T., Nieminen, M., Siren, J., Wong, S. C., Lehtonen, R., \& Hanski, I. (2016). Predictable allele frequency changes due to habitat fragmentation in the Glanville fritillary butterfly. Proc Natl Acad Sci U S A, 113 (10), 2678-2683. doi:10.1073/pnas.1600951113

Fytrou, A., Schofield, P. G., Kraaijeveld, A. R., \& Hubbard, S. F. (2006). Wolbachia infection suppresses both host defence and parasitoid counter-defence. Proc Biol Sci, 273 (1588), 791-796. doi:10.1098/rspb.2005.3383

Gagic, V., Hanke, S., Thies, C., Scherber, C., Tomanovic, Z., \& Tscharntke, T. (2012). Agricultural intensification and cereal aphid-parasitoid-hyperparasitoid food webs: network complexity, temporal variability and parasitism rates. Oecologia, 170 (4), 1099-1109. doi:10.1007/s00442-012-2366-0

Gagic, V., Tscharntke, T., Dormann, C. F., Gruber, B., Wilstermann, A., \& Thies, C. (2011). Food web structure and biocontrol in a four-trophic level system across a landscape complexity gradient. Proc Biol Sci, 278 (1720), 2946-2953. doi:10.1098/rspb.2010.2645

Goldson, S. L., Wratten, S. D., Ferguson, C. M., Gerard, P. J., Barratt, B. I. P., Hardwick, S., . . . Tomasetto, F. (2014). If and when succesful classical biological control fails. Biological control, 72 , 76-79. doi:10.1016/j.biocontrol.2014.02.012

Grangirard, J., Hoddle, M., Petit, J., Roderick, G., \& Davies, N. (2009). Classical biological control of the glassy-winged sharpshooter,Homalodisca vitripennis, by the egg parasitoid Gonatocerus ashmeadi in the Society, Marquesas and Austral archipelagos of French Polynesia. Biological control, 48 (2), 155-163. doi:10.1016/j.biocontrol.2008.10.005

Gruntenko, N. E., Ilinsky, Y. Y., Adonyeva, N. V., Burdina, E. V., Bykov, R. A., Menshanov, P. N., \& Rauschenbach, I. Y. (2017). Various Wolbachia genotypes differently influence host Drosophiladopamine metabolism and survival under heat stress conditions. BMC Evolutionary Biology, 17 (252). doi:10.1186/s12862-017-1104-y

Gruntenko, N. E., Karpova, E. K., Adonyeva, N. V., Andreenkova, O. V., Burdina, E. V., Ilinsky, Y. Y., . . . Rauschenbach, I. Y. (2019). Drosophila female fertility and juvenile hormone metabolism depends on the type of Wolbachia infection. J Exp Biol, 222 (Pt 4). doi:10.1242/jeb.195347

Hanski, I., Ehrlich, P. R., Nieminen, M., Murphy, D. D., Hellmann, J. J., Boggs, C. L., \& McLaughlin, J. F. (2004). Checkerspots and conservation biology. In P. R. Ehrlich \& I. Hanski (Eds.), On the wings of checkerspots: A model system for population biology : Oxford University Press.

Hanski, I., Pakkala, T., Kuussaari, M., \& Lei, G. (1995). Metapopulation persistence of an endangered butterfly in a fragmented landscape. OIKOS, 72 (1), 21-28. doi:10.2307/3546033

Hanski, I., Schulz, T., Wong, S. C., Ahola, V., Ruokolainen, A., \& Ojanen, S. P. (2017). Ecological and genetic basis of metapopulation persistence of the Glanville fritillary butterfly in fragmented landscapes. nature communications, 8 , 14504. doi:10.1038/ncomms14504

Hanski, I. A. (2011). Eco-evolutionary spatial dynamics in the Glanville fritillary butterfly. Proc Natl Acad Sci U S A, 108 (35), 14397-14404. doi:10.1073/pnas.1110020108

Hedges, L. M., Brownlie, J. C., O'Neill, S. L., \& Johnson, K. N. (2008). Wolbachia and virus protection in insects. Science, 322 (5902), 702. doi:10.1126/science.1162418

Hornett, E. A., Charlat, S., Duplouy, A. M., Davies, N., Roderick, G. K., Wedell, N., \& Hurst, G. D. (2006). Evolution of male-killer suppression in a natural population. PLoS Biol, 4 (9), e283. doi:10.1371/journal.pbio.0040283

Hufbauer, R. A., Bogdanowicz, S. M., \& Harrison, R. G. (2004). The population genetics of a biological control introduction: mitochondrial DNA and microsatellie variation in native and introduced populations of Aphidus ervi , a parasitoid wasp. Molecular Ecology, 13 (2), 337-348. 
Kaartinen, R., \& Roslin, T. (2011). Shrinking by numbers: landscape context affects the species composition but not the quantitative structure of local food webs. J Anim Ecol, 80 (3), 622-631. doi:10.1111/j.13652656.2011.01811.x

Kraaijeveld, A. R., Van Alphen, J. J., \& Godfray, H. C. (1998). The coevolution of host resistance and parasitoid virulence.Parasitology, 116 Suppl , S29-45. doi:10.1017/s0031182000084924

Kritani, K., \& Yamamura, K. (2003). Exotic insects and their pathways for invasion. In J. Carlton (Ed.), Invasive species: vectors and management strategies (pp. 44-67). Washington D.C.: Island Press.

Kuussaari, M., van Nouhuys, S., Hellmann, J. J., \& Singer, M. C. (2004). Larval biology of checkerspots. In P. R. Ehrlich \& I. Hanski (Eds.), On the wings of checkerspots: A model system for population biology (pp. 138-160). Oxford: Oxford University Press.

Lei, G., \& Hanski, I. (1998). Spatial dynamics of two competing specialist parasitoids in a host metapopulation. Journal of Animal Ecology, 67 (3), 422-433. doi:10.1046/j.1365-2656.1998.00204.x

Lei, G. C., Vikberg, V., Nieminen, M., \& Kuussaari, M. (1997). The parasitoid complex attacking Finnish populations of the Glanville fritillary Melitaea cinxia (Lep: Nymphalidae), an endangered butterfly. Journal of Natural History, 31 (4), 635-648. doi:10.1080/00222939700770301

Lu, M., Hulcr, J., \& Sun, J. (2016). The role of symbiotic microbes in insect invasions. Annual Review of Ecology, Evolution, and Systematics, 47 , 487-505. doi:10.1146/annurev-ecolsys-121415-032050

Martinez, J., Cogni, R., Cao, C., Smith, S., Illingworth, C. J., \& Jiggins, F. M. (2016). Addicted? Reduced host resistance in populations with defensive symbionts. Proc Biol Sci, 283 (1833). doi:10.1098/rspb.2016.0778

Mattila, A. L. K., Duplouy, A., Kirjokangas, M., Lehtonen, R., Rastas, P., \& Hanski, I. (2012). High genetic load in an old isolated butterfly population. Proceedings of the National Academy of Sciences of the United States of America, 109 (37), E2496-E2505. doi:10.1073/pnas.1205789109

Meirmans, P. G., \& van Tienderen, P. H. (2004). GENOTYPE and GENODIVE: two programs for the analysis of genetic diversity of asexual organisms.Molecular Ecology Notes, 4 , 792-794.

Miller, E. J., Eldridge, M. D. B., Morris, K. D., Zenger, K. R., \& Herbert, C. A. (2011). Genetic consequences of isolation: island tammar wallaby (Macropus eugenii) populations and the conservation of threatened species. Conservation Genetics, 12 (6), 1619-1631. doi:10.1007/s10592-011-0265-2

Montovan, K. J., Couchoux, C., Jones, L. E., Reeve, H. K., \& van Nouhuys, S. (2015). The puzzle of partial resource use by a parasitoid wasp. Am Nat, 185 (4), 538-550. doi:10.1086/680036

Murphy, D. D., Wahlberg, N., Hanski, I., \& Ehrlich, P. R. (2004). Introducing Checkerspots: taxonomy and ecology. In P. R. Ehrlich \& I. Hanski (Eds.), On the wings of Checkerspots: a model system for population biology (pp. 17-33). New York: Oxford University Press.

Nair, A., Fountain, T., Ikonen, S., Ojanen, S. P., \& van Nouhuys, S. (2016). Spatial and temporal genetic structure at the fourth trophic level in a fragmented landscape. Proc Biol Sci, 283 (1831). doi:10.1098/rspb.2016.0668

Nei, M., Marutama, T., \& Chakraborty, R. (1975). The bottleneck effect and genetic variability in populations. Evolution, 29 , 1-10.

O'Neill, S., Hoffman, A., \& Werren, J. (1997). Influencial passengers, inherited microorganisms and arthropod reproduction. NY: Oxford University Press Inc.

O'Brien, E., Jorde, L. B., Ronnlof, B. F., J. O., \& Eriksson, A. W. (1988). Inbreeding and genetic disease in Sottunga, Finland.American Journal of Physical Anthropology, 75 , 477-486. 
Ojanen, S. P., Nieminen, M., Meyke, E., Poyry, J., \& Hanski, I. (2013). Long-term metapopulation study of the Glanville fritillary butterfly (Melitaea cinxia ): survey methods, data management, and long-term population trends. Ecol Evol, 3 (11), 3713-3737. doi:10.1002/ece3.733

Osborne, S. E., Iturbe-Ormaetxe, I., Brownlie, J. C., O'Neill, S. L., \& Johnson, K. N. (2012). Antiviral protection and the importance of Wolbachia density and tissue tropism in Drosophila simulans . Appl Environ Microbiol, 78 (19), 6922-6929. doi:10.1128/AEM.01727-12

Pasek, J. E. (1988). Influence of wind and windbreaks on local dispersal of insects. Agric Ecosyst Environ, 22 (23), 539-554.

Schuler, H., Koppler, K., Daxbock-Horvath, S., Rasool, B., Krumbock, S., Schwarz, D., . . . Riegler, M. (2016). The hitchhiker's guide to Europe: the infection dynamics of an ongoing Wolbachia invasion and mitochondrial selective sweep in Rhagoletis cerasi . Mol Ecol, 25 (7), 1595-1609. doi:10.1111/mec.13571

Shaw, M. R., Stefanescu, C., \& Van Nouhuys, S. (2009). Parasitoids of European butterflies In J. Settele, T. G. Shreeve, M. Konvicka, \& H. Van Dyck (Eds.), Ecology of butterflies in Europe. Cambridge: Cambridge University Press.

Signor, S. (2017). Population genomics of Wolbachia and mtDNA inDrosophila simulans from California. Sci Rep, 7 (1), 13369. doi:10.1038/s41598-017-13901-3

Szucs, M., Melbourne, B. A., Tuff, T., \& Hufbauer, R. A. (2014). The roles of demography and genetics in the early stages of colonization.Proceedings of the Royal Society B-Biological Sciences, 281 (1792). doi:10.1098/rspb.2014.1073

Urquia, D., Gutierrez, B., Pozo, G., Pozo, M. J., Espin, A., \& Torres, M. L. (2019). Psidium guajava in the Galapagos Islands: Population genetics and history of an invasive species. PLoS One, 14 (3), e0203737. doi:10.1371/journal.pone.0203737

van Bergen, E., Dallas, T., DiLeo, M. F., Kahilainen, A., Mattila, A. L. K., Luoto, M., \& Saastamoinen, M. (2020). The effect of summer drought on the predictability of local extinctions in a butterfly metapopulation. Conserv Biol . doi:10.1111/cobi.13515

van Nouhuys, S. (2005). Effects of habitat fragmentation at different trophic levels in insect communities. Annales Zoologici Fennici, 42 (4), 433-447.

van Nouhuys, S., \& Ehrnsten, J. (2004). Wasp behavior leads to uniform parasitism of a host available only a few hours per year.Behavioral Ecology, 15 (4), 661-665. doi:10.1093/beheco/arh059

van Nouhuys, S., \& Hanski, I. (2002). Colonization rates and distances of a host butterfly and two specific parasitoids in a fragmented landscape. Journal of Animal Ecology, 71 , 639-650.

van Nouhuys, S., \& Hanski, I. (2005). Metacommunities of butterflies, their host plants and their parasitoids. In M. Holyoak, M. A. Leibold, \& R. D. Holt (Eds.), Metacommunities: Spatial dynamics and ecological communities (pp. 99-121). Chicago, USA: University of Chicago Press.

van Nouhuys, S., Kohonen, M., \& Duplouy, A. (2016). Wolbachiaincreases the susceptibility of a parasitoid wasp to hyperparasitism.J Exp Biol, 219 (Pt 19), 2984-2990. doi:10.1242/jeb.140699

van Nouhuys, S., Niemikapee, S., \& Hanski, I. (2012). Variation in a host-parasitoid interaction across independent populations.Insects, 3 (4), 1236-1256. doi:10.3390/insects3041236

Verne, S., Johnson, M., Bouchon, D., \& Grandjean, F. (2012). Effects of parasitic sex-ratio distorters on host genetic structure in theArmadillidium vulgare - Wolbachia association. J Evol Biol, 25 (2), 264-276. doi:10.1111/j.1420-9101.2011.02413.x

Wang, Z., Liu, Y., Shi, M., Huang, J., \& Chen, X. (2019). Parasitoid wasps as effective biological control agents. Journal of Intergrative Agriculture, 18 (4), 705-715. doi:10.1016/S2095-3119(18)62078-7 
Zhou, W., Rousset, F., \& O'Neil, S. (1998). Phylogeny and PCR-based classification of Wolbachia strains using wsp gene sequences. Proc Biol Sci, 265 (1395), 509-515. doi:10.1098/rspb.1998.0324

Data accessibility

Raw data and analyses are available in the supplementary material.

\section{Author contributions}

$\mathrm{AD}, \mathrm{AN} \& \mathrm{SvN}$ designed the research. AD and TN produced the data. AD and AN analysed the data. AD wrote the paper. All authors contributed on the manuscript.

Tables

Table 1: Sample size, observed $\left(H_{O}\right)$ and expected heterozygosities $\left(H_{E}\right)$, and inbreeding coefficient (Fis) for Hyposoter horticola from each locality, with mitotype and infection status by the Wolbachiastrain $\boldsymbol{w H h o . ~ V a l u e s ~ o f ~} H_{O}, H_{E}$ and Fis are calculated based on female data only, all other values are based on both male and female data. Number of genetic clusters were calculated using an across Aland individual cluster Bayesian analysis $\left(\mathrm{N}_{\mathrm{Pop}}=1\right)$.

\begin{tabular}{llllll}
\hline Locality & Female data only & Female data only & Female data only & Female data only & Male an \\
\hline & Genotyping & Genotyping & Genotyping & Genotyping & Genotyp \\
& $\mathbf{N}_{\text {total }}\left(\mathbf{N}_{\text {clusters }}\right)$ & $\mathrm{H}_{\mathrm{O}}$ & $\mathrm{H}_{\mathrm{E}}$ & Fis & $\mathbf{N}_{\text {total }}(\mathrm{N}$ \\
Finström & $50(10)$ & 0,401 & 0,524 & 0,234 & $96(25)$ \\
Föglö & $21(4)$ & 0,279 & 0,375 & 0,258 & $43(13)$ \\
Seglinge-Kumlinge & $19(5)$ & 0,296 & 0,389 & 0,240 & $44(10)$ \\
Saltvik & $85(13)$ & 0,403 & 0,488 & 0,177 & $101(23)$ \\
Sottunga & $20(6)$ & 0,330 & 0,416 & 0,206 & $40(13)$ \\
Total & $195(16)$ & 0,342 & 0,438 & 0,222 & $324(31)$ \\
\hline
\end{tabular}

Table 2: Genetic clusters and total sample size of the 12 spatio-temporal groups. Observed $\left(H_{O}\right.$ ) and expected heterozygosities $\left(H_{E}\right)$, and inbreeding coefficient (Fis) were calculated using only the data from diploid females.

\begin{tabular}{|c|c|c|c|c|c|c|c|c|}
\hline Locality & Period & $\begin{array}{l}\text { Clusters } \\
\text { (Fig. 3) }\end{array}$ & $\begin{array}{l}\mathbf{N}= \\
\left(\mathrm{N}_{\text {female }}=\right)\end{array}$ & $\mathrm{H}_{\mathrm{O}}$ & $\mathrm{H}_{\mathrm{E}}$ & Fis & $\begin{array}{l}\text { Mitotype } \\
\text { C }(\mathrm{N}=)\end{array}$ & $\begin{array}{l}\text { Infect } \\
\text { rate } \\
(\mathrm{N}=)\end{array}$ \\
\hline Finström & $1992-98$ & red & $28(12)$ & 0,46 & 0,491 & 0,063 & $\begin{array}{l}88,9 \% \\
(8 / 9)\end{array}$ & $\begin{array}{l}7,1 \% \\
(2 / 28)\end{array}$ \\
\hline Finström & 2001-08 & green & $14(8)$ & 0,429 & 0,535 & 0,197 & $\begin{array}{l}87,5 \% \\
(7 / 8)\end{array}$ & $\begin{array}{l}35,7 \% \\
(5 / 14)\end{array}$ \\
\hline Finström & 2009-11 & green & $53(30)$ & 0,381 & 0,517 & 0,264 & $\begin{array}{l}80 \% \\
(16 / 20)\end{array}$ & $\begin{array}{l}62 \% \\
(31 / 50\end{array}$ \\
\hline Föglö & 2000-09 & red & $19(7)$ & 0,325 & 0,439 & 0,259 & $\begin{array}{l}88,2 \% \\
(15 / 17)\end{array}$ & $\begin{array}{l}17,6 \% \\
(3 / 17)\end{array}$ \\
\hline Föglö & 2010-13 & blue & $24(14)$ & 0,255 & 0,313 & 0,184 & $\begin{array}{l}100 \% \\
(24 / 24)\end{array}$ & $\begin{array}{l}41,7 \% \\
(10 / 24\end{array}$ \\
\hline $\begin{array}{l}\text { Seglinge- } \\
\text { Kumlinge }\end{array}$ & 2000-09 & yellow & $30(15)$ & 0,306 & 0,345 & 0,112 & $\begin{array}{l}27,6 \% \\
(8 / 29)\end{array}$ & $\begin{array}{l}96,2 \% \\
(25 / 26\end{array}$ \\
\hline $\begin{array}{l}\text { Seglinge- } \\
\text { Kumlinge }\end{array}$ & 2010-11 & red & $14(4)$ & 0,185 & 0,449 & 0,589 & $\begin{array}{l}28,6 \% \\
(4 / 14)\end{array}$ & $\begin{array}{l}92,9 \% \\
(13 / 14\end{array}$ \\
\hline Saltvik & 1999 & red & $2(2)$ & 0,318 & 0,477 & 0,333 & $0 \%(0 / 2)$ & $100 \%$ \\
\hline
\end{tabular}




\begin{tabular}{|c|c|c|c|c|c|c|c|c|}
\hline Locality & Period & $\begin{array}{l}\text { Clusters } \\
\text { (Fig. 3) }\end{array}$ & $\begin{array}{l}\mathbf{N}= \\
\left(\mathrm{N}_{\text {female }}=\right)\end{array}$ & $\mathrm{H}_{\mathrm{O}}$ & $\mathrm{H}_{\mathrm{E}}$ & Fis & $\begin{array}{l}\text { Mitotype } \\
\text { C }(\mathrm{N}=)\end{array}$ & $\begin{array}{l}\text { Infect } \\
\text { rate } \\
(\mathrm{N}=)\end{array}$ \\
\hline $\begin{array}{l}\text { Saltvik } \\
\text { nalo }\end{array}$ & 2005-09 & red & $74(64)$ & 0,442 & 0,472 & 0,065 & $\begin{array}{l}48,7 \% \\
(19 / 39)\end{array}$ & $\begin{array}{l}59,3 \% \\
(35 / 59)\end{array}$ \\
\hline Saltvik & 2010-13 & red & $25(19)$ & 0,274 & 0,538 & 0,49 & $\begin{array}{l}69,6 \% \\
(16 / 23)\end{array}$ & $\begin{array}{l}64 \% \\
(16 / 25)\end{array}$ \\
\hline Sottunga & 2002-04 & yellow & $22(9)$ & 0,304 & 0,367 & 0,172 & $\begin{array}{l}81 \% \\
(17 / 21)\end{array}$ & $\begin{array}{l}31,8 \% \\
(7 / 22)\end{array}$ \\
\hline Sottunga & 2005-09 & yellow & $18(11)$ & 0,377 & 0,407 & 0,073 & $\begin{array}{l}58,8 \% \\
(10 / 17)\end{array}$ & $\begin{array}{l}11,8 \% \\
(2 / 17)\end{array}$ \\
\hline
\end{tabular}

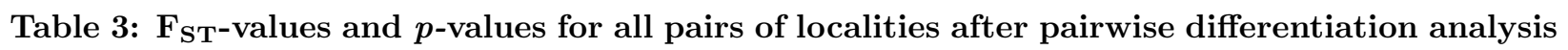
based on 311 samples from five localities, under and above the diagonal, respectively. Bold values highlight the results of the comparison between Sottunga and Seglinge-Kumlinge. (*) Significance for $\alpha<0.05$, and $(* *) \alpha<0.01$.

\begin{tabular}{llllll}
\hline F & Finström $/ \boldsymbol{p}$-values & Föglö & Seglinge-Kumlinge & Saltvik & Sottunga \\
\hline Finström & - & $p=0.001^{* *}$ & $p=0.001^{* *}$ & $p=0.001^{* *}$ & $p=0.001^{* *}$ \\
Föglö & 0.068 & - & $p=0.001^{* *}$ & $p=0.001^{* *}$ & $p=0.001^{* *}$ \\
Seglinge-Kumlinge & 0.125 & 0.135 & - & $p=0.001^{* *}$ & $p=\mathbf{0 . 0 4 2 ^ { * }}$ \\
Saltvik & 0.054 & 0.077 & 0.126 & - & $p=0.001^{* *}$ \\
Sottunga & 0.111 & 0.113 & $\mathbf{0 . 0 1 4 ^ { * }}$ & 0.115 & - \\
\hline
\end{tabular}




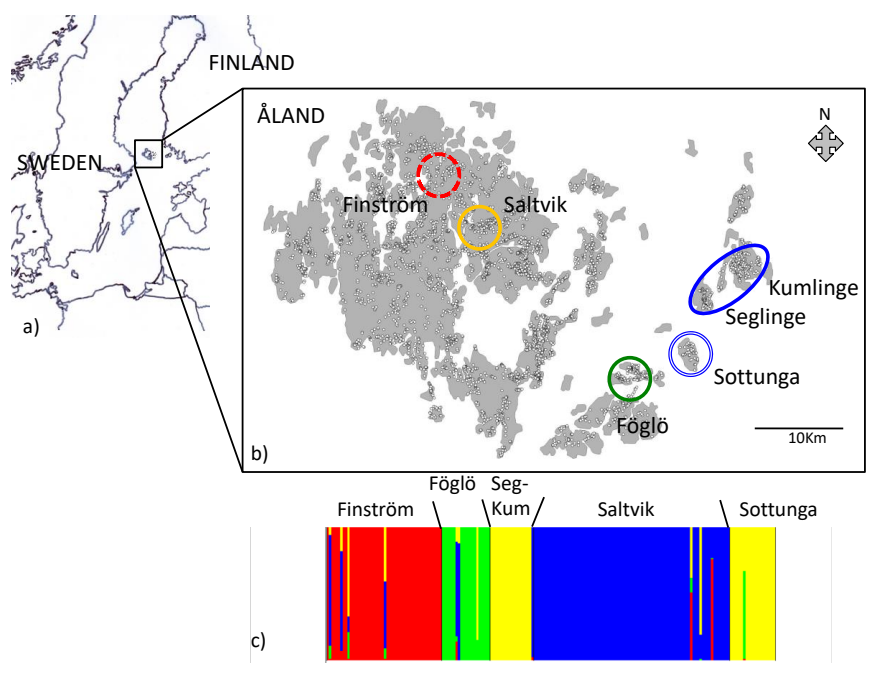

Figure1: The Åland archipelago and the genetic diversity across five local populations of the parasitoid wasp Hyposoter horticola. (a) Åland stands in the Baltic Sea, between the coasts of Finland and Sweden. (b) Samples used in the study originated from the local communes of Finström, Föglö, Kumlinge, Saltvik and Sottunga. The small white dots represent all currently known habitat patches of the Glanville fritillary butterfly (Ojanen et al., 2013). Melitaea cinxia caterpillars that were parasitized by Hyposoter horticola and the hyperparasitoid Mesochorus cf. stigmaticus were introduced to Sottunga (dashed yellow) from Finström (red) in 1991. (c) The genetic clusters, based on five populations clustering of groups of individuals analysis $(k=4, p=0.999)$, with admixture. 


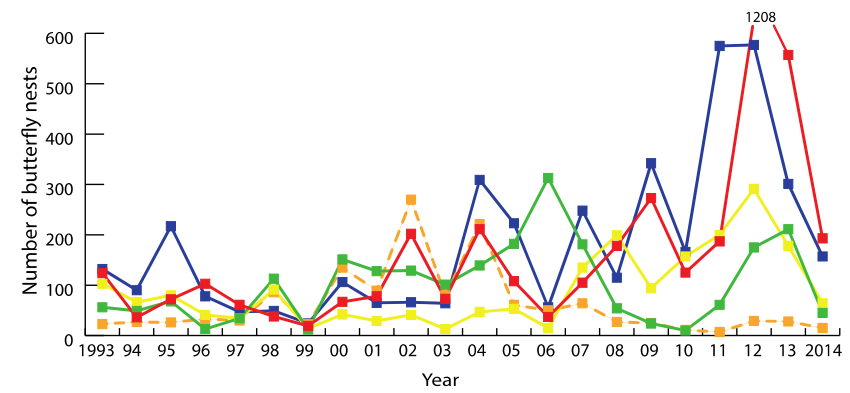

Figure 2: The number of nests of the Glanville fritillary butterfly, Melitaea cinxia,

between 1993 to 2014 in five areas of the Åland archipelago. Finström (red), Saltvik (blue),

Föglö (green), Sottunga (dashed yellow) and Kumlinge-Seglinge (yellow) (Figure adapted

from data included in Fountain et al. 2018 (Fountain et al., 2018)). The number '1208'

indicates the exceptional large number of nests in Finström in 2012. 


\begin{tabular}{|c|c|c|c|c|c|}
\hline Locality & \multicolumn{2}{|c|}{ Spatio-temporal group } & Genotypic & Main & Admixture \\
\hline \multirow{3}{*}{ Finström } & $1992-97$ & (Red) & & $13-26-31$ & \\
\hline & 2001-08 & (Green) & & $5-2$ & \\
\hline & 2009-11 & (Green) & & $15-26-29-$ & \\
\hline \multirow{2}{*}{ Föglö } & $2000-09$ & (Red) & & 15 & \\
\hline & $2010-10$ & (Bleu) & & $19-27$ & \\
\hline Kumlinge & 2000-09 & (Yellow) & & $\begin{array}{c}1-6-13 \\
8\end{array}$ & \\
\hline \multirow{3}{*}{ Saltvik } & 1999 & (Red) & & $5-6-9$ & \\
\hline & 2005-09 & (Red) & & $10-13-22$ & \\
\hline & 2010-13 & (Red) & & $5-9-13-26$ & \\
\hline \multirow{2}{*}{ Sottunga } & 2002-04 & (Yellow) & & $5-9-17$ & - \\
\hline & 2005-09 & (Yellow) & & 9 & \\
\hline \multirow{4}{*}{\multicolumn{6}{|c|}{$\begin{array}{l}\text { Figure 3: The four genotypic clusters of Hyposoter horticola based on clustering of } 12 \\
\text { spatio-temporal groups of individuals analysis }(\mathbf{k}=\mathbf{4}, \mathbf{p}=\mathbf{0 . 9 9 1 )} \text {, (left) without and (right) } \\
\text { with admixture results, and (center) the most common individual clusters in each spatio- } \\
\text { temporal group. The main clusters were characterized through the individual. }\end{array}$}} \\
\hline & & & & & \\
\hline & & & & & \\
\hline & & & & & \\
\hline & & & & & \\
\hline
\end{tabular}

